\title{
Evaporation of Topopah Spring Tuff Pore Water
}

\author{
N.D. Rosenberg, K.G. Knauss, M.J. Dibley
}

\section{September 10, 1999}

U.S. Department of Energy

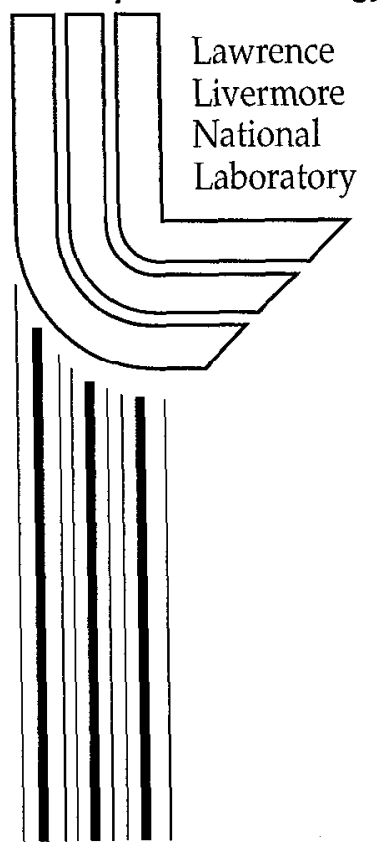




\section{DISCLAIMER}

This document was prepared as an account of work sponsored by an agency of the United States Government. Neither the United States Government nor the University of California nor any of their employees, makes any warranty, express or implied, or assumes any legal liability or responsibility for the accuracy, completeness, or usefulness of any information, apparatus, product, or process disclosed, or represents that its use would not infringe privately owned rights. Reference herein to any specific commercial product, process, or service by trade name, trademark, manufacturer, or otherwise, does not necessarily constitute or imply its endorsement, recommendation, or favoring by the United States Government or the University of California. The views and opinions of authors expressed herein do not necessarily state or reflect those of the United States Government or the University of California, and shall not be used for advertising or product endorsement purposes.

Work performed under the auspices of the U. S. Department of Energy by the University of California Lawrence Livermore National Laboratory under Contract W-7405-Eng-48.

This report has been reproduced directly from the best available copy.

Available to DOE and DOE contractors from the Office of Scientific and Technical Information

P.O. Box 62, Oak Ridge, TN 37831

Prices available from (423) 576-8401

http://apollo.osti.gov/bridge/

Available to the public from the

National Technical Information Service

U.S. Department of Commerce

5285 Port Royal Rd., Springfield, VA 22161

http://www.ntis.gov/

OR

Lawrence Livermore National Laboratory

Technical Information Department's Digital Library

http://www.llnl.gov/tid/Library.html 


\title{
Evaporation of Topopah Spring Tuff Pore Water
}

\author{
N. D. Rosenberg, K. G. Knauss, M. J. Dibley
}

Geosciences and Environmental Technologies Division

Lawrence Livermore National Laboratory

Livermore, CA 94551

September 10, 1999 


\begin{abstract}
We report on the results to date for experiments on the evaporative chemical evolution of a $\mathrm{CaSO}_{4}$-rich water representative of Topopah Spring Tuff porewater from Yucca Mountain. Data include anion and cation analysis and qualitative mineral identification for a series of open system experiments, with and without crushed tuff present, conducted at sub-boiling temperatures.
\end{abstract}


Table of Contents

page

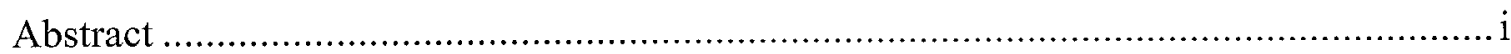

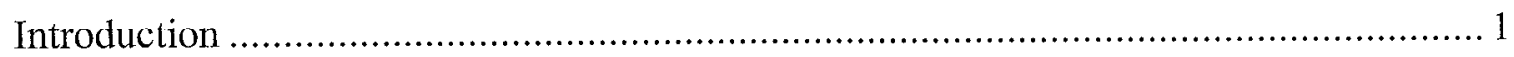

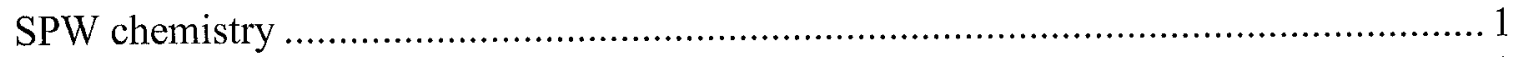

Origin of SPW model composition .............................................................. 1

Making synthetic SPW in the laboratory .................................................... 2

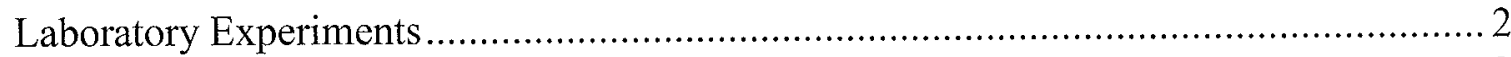

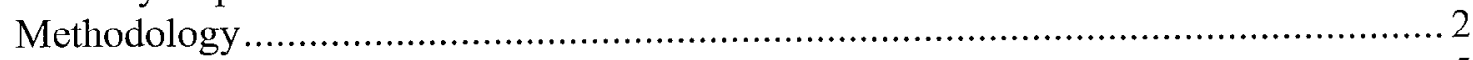

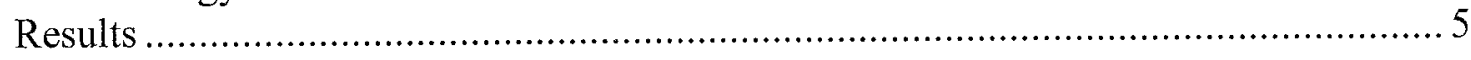

Discussion, Modeling and Conclusions ........................................................... 5

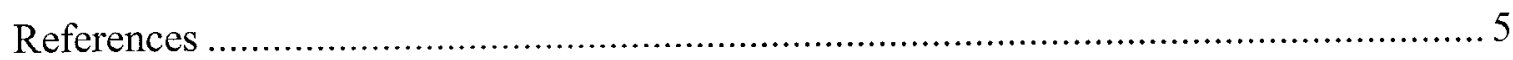

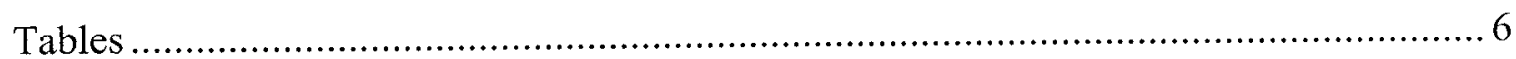




\section{Introduction}

The evaporative chemical evolution of near-field waters that might seep onto waste packages at the potential nuclear waste repository at Yucca Mountain is an important factor in assessing repository performance and safety. Of particular interest with respect to waste package corrosion are $\mathrm{pH}$, concentrations of the anions (e.g., $\mathrm{Cl}, \mathrm{F}, \mathrm{NO}_{3}, \mathrm{SO}_{4}$ ), the oxygen potential ( $\mathrm{Eh}$ ), the nature of salts that may precipitate on the waste package surfaces, and the deliquescence point of those salts. The evaporative chemical evolution of near-field waters is also of concern in the assessment of potential radionuclide solubility and transport. With respect to these processes, the parameters $\mathrm{pH}, \mathrm{Eh}$, the concentration of specific metal-complexing anions, and total ionic strength are particularly important.

The chemical composition of near-field waters that might seep into drifts containing waste packages is the subject of much discussion within the Yucca Mountain Project. This report focuses on the evaporative chemical evolution of synthetic pore water (SPW), a water representative of repository horizon (Topopah Spring Tuff) porcwater, which has a $\mathrm{CaSO}_{4}$-rich composition (Sonnenthal, et al., 1998).

This report has two main sections. The first is a presentation of pore water chemistry and a discussion of making SPW in the laboratory. The second is a description of the evaporation experiments we conducted with SPW. These experiments include open system experiments, with and without crushed tuff present, conducted at temperatures of $75-85^{\circ} \mathrm{C}$. These experiments are meant to be representative of sub-boiling conditions in the repository, conditions which would likely exist both before and after the height of the thermal pulse caused by decaying radioactive waste. This is a status report on these experiments. No analysis or modeling is included in this report.

\section{SPW chemistry}

\section{Origin of SPW model composition}

As noted by Sonnenthal et al. (1998), attempts to acquire pore water samples from the repository horizon at Yucca Mounlain and analyze them in a useful way are on-going. This is a difficult undertaking fraught with pitfalls. The very act of acquiring the samples (e.g. ultracentrifugation, squeezing in a triaxial press) can alter the water composition. Even if a perfectly representative sample could be obtained, preserving the sample chemically intact prior to analyses by avoiding all possible alterations to the composition (e.g., equilibration with the atmosphere) is also difficult.

Sonnenthal et al. (1998) evaluated the validily of reported pore water compositions using thermodynamic chemical speciation calculations. They concluded that for some elements the reported compositions seemed thermodynamically reasonable, whereas for others it seemed more reasonable to simply assume that the waters were in chemical equilibrium with specific minerals present in the rock. We decided to follow their approach and we used Table 11.1 in Sonnenthal 
et al. (1998) as a starting point. We calculated a $25^{\circ} \mathrm{C}$ composition for Topopah Spring Tuff pore water at Yucca Mountain using the code EQ3/6 (Wolery, 1998). The results are shown in Table 1.

\section{Making synthetic SPW in the laboratory}

Making SPW in the laboratory is not as straightforward as it may appear. The measured mean composition of SPW is supersaturated with respect to the solubility of a number of minerals at $25^{\circ} \mathrm{C}$. These include many of the primary minerals in the tuff (e.g. quartz, albite, $\mathrm{K}$-feldspar, cristobalite), as well as secondary minerals commonly found in the tuff (e.g. chalcedony, tridymite, kaolinite, illite, montmorillonite).

Unfortunately, adding readily soluble sources of the various components of SPW (e.g., sodium metasilicate for $\mathrm{Si}$ ) to distilled water in the laboratory will not result in a solution with the exact composition of SPW either. In order to add sufficient Si from that source, one also adds too much $\mathrm{Na}$ and increases the $\mathrm{pH}$ too much (the metasilicate solution has very high $\mathrm{NaOH}$, precisely because $\mathrm{Si}$ is relatively insoluble).

To make SPW for our experiments, we mixed a solution at room temperature, aiming for an approximate SPW composition based on Table 1, and stirred the solution for several days. The solution was then decanted to remove any undissolved reagents. The resulting solution was analyzed for the solutes of interest: $\mathrm{C}, \mathrm{Ca}, \mathrm{Cl}, \mathrm{F}, \mathrm{K}, \mathrm{Mg}, \mathrm{N}, \mathrm{Na}, \mathrm{S}, \mathrm{Si}$. The $\mathrm{pH}$ was also measured. The average composition of SPW used in our experiments is given in Table 2. Throughout this report, when we refer to SPW for a particular experiment, we use the actual composition for that specific experiment as determined by analysis, rather than the average reported in Table 2 or an estimate based on our SPW "recipe". Note that the concentration data reported in tables are rounded to the nearest significant figure. However, for data retrieval purposes, in spreadsheet calculations and plotting of derived values, more than the number of significant figures are included in the calculation to minimize rounding errors.

\section{Laboratory Experiments}

\section{Methodology}

The laboratory batch experiments with SPW conducted at LLNL in 1998-1999 are completely analogous to those done earlier with J13 water (Rosenberg et al., 1999).

In the first two experiments, $30 \mathrm{~L}$ of synthetic J13 water were evaporated down to approximately $30 \mathrm{~mL}$ of solution. In all experiments, actual concentration factors wcre cstimatcd by mass measurements. We estimate that these concentration factors are accurate to approximately $10 \%$. The SPW solution was pumped into a $1 \mathrm{~L}$ pyrex beaker at a constant rate using a peristaltic pump while the sample evaporatively concentrated at $85^{\circ} \mathrm{C}$ with a hot plate as the heat source. The fluid delivery rate and heat flux were balanced to maintain constant temperature in the fluid 
contained within the beaker. Note that the temperature and heat flux used in these experiments are not intended to mimic exactly any one particular repository scenario. However, the assemblage of mineral phases that result from the evaporation of this fluid is primarily controlled by precipitation kinetics at these temperatures, and therefore we expect the minerals assemblages we observe to be representative of repository conditions in general.

In the first experiment (evap3), detailed water chemistry measurements were made on the starting fluid ( 3 separate batches) and on a sample collected from the beaker after approximately evaporative concentration. A small split of the solids that had precipitated were also removed at this point for mineralogical analysis. The solution was then evaporated completely to dryness and another small split of the solids was again removed for mineralogical analysis. The salts were then rewet with $200 \mathrm{~mL}$ of deionized water, evaporatively concentrated down to $100 \mathrm{~mL}$ at $75^{\circ} \mathrm{C}$ and the resulting solution was collected for detailed water chemistry analysis. The actual temperature and volumes used in the rewetting were not intended to represent any particular repository-specific scenario. Rather, they simply provide an empiric, if arbitrary, estimate of the effect of rewetting dry salts resulting from the complete evaporation of the SPW. This experiment was designed to investigate the evolving fluid chemistry and mineralogy as pore water-like water is evaporatively concentrated and various minerals precipitate from solution as the fluid becomes supersaturated with respect to their solubility. In total, two aqueous samples and two solid samples were analyzed from this experiment, in addition to the starting fluid.

In a second experiment (evap6), the experimental protocol was nearly identical to the first experiment (evap3) with the exception that the beaker contained $10 \mathrm{~g}$ of crushed Topopah Spring Tuff (Yucca Mountain Site Characterization Project Sample Management Facility Specimen ID \#00521699). The grains were prepared by sieving the originally $<2 \mathrm{~mm}$ sample to $>0.5 \mathrm{~mm}$ in order to remove the fine fraction. The sized material was then washed three times in isopropanol, and the grains allowed to settle before decanting to remove adhering fine particles, and allowed to air dry. In this experiment we investigated the effect of the presence of tuff on the evolving fluid chemistry and mineralogy. This experiment also produced two aqueous samples and two solid samples for analysis, in addition to the starting fluid.

We measured the $\mathrm{pH}$ of the rewet samples for both the evap3 and evap6 experiments. Because solution $\mathrm{pH}$ is a key parameter, we conducted a third experiment (evap5) designed to focus on the short term evolution of $\mathrm{pH}$. Carbonate measurements are also reported for this experiment. In addition, we sampled the fluid twice, at the start of the run and at the end, for complete chemical analysis.

The aqueous samples for cation and anion analyses were collected in plastic syringes. The aliquots were filtered through a $0.45 \mu \mathrm{m}$ filter ahead of a syringe that had been preloaded with deionized water. The fluid for cation analysis was then delivered into a plastic sample tube, further diluted with water and spiked with a concentrated acid solution. The total dilution was approximately 10 to 15 -fold in the sample submitted for cation analysis. The anion aliquot was collected in a similar manner (i.c., prefiltered and diluted with deionized water). However, the anion sample syringe was emptied into a glass sample vial. A small split of the anion sample was directly injected into an infared $\mathrm{CO}_{2}$ analyzer in the Geochemistry Laboratory, Building 281 at LLNL, to determine total $\mathrm{CO}_{2}$. 
The following chemical analyses were performed:

- anions in solution

- cations in solution

- $\mathrm{pH}$ of solution

- minerals present in solids (qualitative).

The procedures for each of these analyses are briefly described below:

Two methods were used for anion analyses. The anions $\mathrm{Cl}, \mathrm{F}, \mathrm{SO}_{4}$ and $\mathrm{NO}_{3}$ were determined using ion chromatography (IC). The analytical protocol used also allows detection and quantification of several other anion analytes, but these four anions were the only ones (other than the carbonate species) present in these solutions. The sample aliquots had to be diluted considerably, owing to the low detection limits for this method. The carbonate anions were determined as total $\mathrm{CO}_{2}$ using an infrared $\mathrm{CO}_{2}$ analyzer and reported as $\mathrm{HCO}_{3}$.

The cation ( $\mathrm{Na}, \mathrm{K}, \mathrm{Ca}, \mathrm{Mg}$ and $\mathrm{Si}$ ) concentrations were determined using inductively-coupled plasma emission spectrometry (ICP). These sample aliquots were also diluted considerably.

The $\mathrm{pH}$ measurements were accomplished by sampling into a plastic syringe and delivering the fluid, at approximately room temperature, gently into a plastic tube containing a calibrated combination $\mathrm{pH}$ electrode. The solution $\mathrm{pH}$ was determined using the NBS standard procedure. Note that the operational definition of measured $\mathrm{pH}$ (Bates, 1964) is intended to provide a convenient, reproducible method to measure $\mathrm{pH}$ potentiometrically in low ionic strength solutions using a cell consisting of a glass $\mathrm{H}^{+}$electrode and a reference electrode with a liquid junction. Strictly speaking, this limits $\mathrm{pH}$ measurement to solutions with less than 0.1 molal ionic strength (see Knauss et al., 1990, 1991 for further discussion), although useful measurement can be made up to seawater ionic strength, $\sim 0.7$ molal, with a little effort. For a water with the approximate ionic strength of SPW, this limits measurement to something less than a 100-fold concentration factor. In effect, this means that the measurement of $\mathrm{pH}$ in the starting solutions and throughout the evap4 experiment are accurate, but those made for the rewet samples of the evap1 and evap 2 runs are only approximations. We did not attempt to make a quantitative measurement of the $\mathrm{pH}$ of the most highly concentrated samples, because the ionic strengths of those samples would exceed that specified by the NBS operational definition of measured $\mathrm{pH}$. In the future if accurate assessment of $\mathrm{H}^{+}$activity is required, other methods outlined in the cited references will be required.

The solids acquired during the these experiments (evap3 and evap6) were analyzed using standard X-ray diffraction (XRD) methods. The primary purpose of the measurement was to identify the phases produced, so no quantification was attempted. Note that phases present in small amounts (a few percent) may not be detected with this approach. The total mass of solids produced was also determined. 


\section{Results}

The results of these cxpcriments are shown in Tables $3-9$.

\section{Discussion, Modeling and Conclusions}

This project was terminated before this work could be completed.

\section{References}

Bates, R. G. 1964. Determination of $\mathrm{pH}$ : theory and practice, John Wiley and Sons, New York, 435 pages. (p. 31).

Knauss, K.G., Wolery, T.J., and Jackson, K.J. 1991. "Reply to comment by R.E. Mesmer on, A new approach to measuring $\mathrm{pH}$ in brines and other concentrated electrolytes." Geochim. Cosmochim. Acta 55:1177-1179.

Knauss, K.G., Wolery, T.J., and Jackson, K.J. 1990. "A new approach to measuring pH in brines and other concentrated electrolytes." Geochim. Cosmochim. Acta 54:1519-1523. Rosenberg, N. D. and K. Knauss (in prep), Evaporation of J-13 water: laboratory experiments and geochemical modeling, Lawrence Livermore National Laboratory document UCRL-ID134852 .

Sonnenthal, E., Spycher, N., and Simmons, A. 1998. Thermo-Hydro-Chemical Predictive Analysis for the Drift-Scale Heat Test. Level 4 Milestone. SPY289M4, V. 1. Berkeley, California: Lawrence Berkeley National Laboratory. MOL.19981130.0132.

Wolery, T. J. 1998. EQ3/6, a software package for geochemical modeling Version 7.2b (UCRLCODE-99015). 


\section{Tables}

Table 1. Modeled composition of SPW at $25^{\circ} \mathrm{C}$

Table 2. Chemistry of average SPW used in the present study

Table 3. Water chemistry from experiment with SPW alone

Table 4. Water chemistry from experiment with SPW with tuff

Table 5. pH and carbonate evolution from short-term experiment with SPW alone

Table 6. Water chemistry from short-term experiment with SPW water alone

Table 7. Mineralogical results from experiment with SPW alone

Table 8. Mineralogical results from experiment with SPW with tuff

Table 9. Mass of minerals formed in experiments with SPW 
Table 1. Modeled composition of SPW at $25^{\circ} \mathrm{C}$

\begin{tabular}{lcc}
\hline Ions & $\mathrm{mg} / \mathrm{L}$ & \\
$\mathrm{H}^{+}$ & 5.6 & $* *$ \\
$\mathrm{Na}^{+}$ & 9. & $*$ \\
$\mathrm{~K}^{+}$ & .01 & $* *$ \\
$\mathrm{Mg}^{++}$ & 12 & $*$ \\
$\mathrm{Ca}^{++}$ & 65 & $*$ \\
$\mathrm{Al}^{+++}$ & 1.3 & $* *$ \\
$\mathrm{SiO}_{2}(\mathrm{aq})$ & 46 & $*$ \\
$\mathrm{HCO}_{3}^{-}$ & 66 & $*$ \\
$\mathrm{SO}_{4}^{-}$ & 79 & $*$ \\
$\mathrm{Cl}^{-}$ & 77 & $*$ \\
$\mathrm{NO}_{3}^{-}$ & 12 & $*$ \\
$\mathrm{~F}^{-}$ & 2 & $* * *$ \\
\hline
\end{tabular}

* = taken directly from Sonnenthal et al. (1998), Table 11.1

** = calculated using constraints suggested in Sonnenthal et al. (1998), Table 11.1

$* * *=$ not in Sonnenthal et al. (1998) composition

Table 2. Chemistry of average SPW used in the present study

\begin{tabular}{ll}
\hline Ions & $\mathrm{mg} / \mathrm{kg}$ \\
$\mathrm{pH}$ & $7.55 \pm 0.12$ \\
$\mathrm{Na}^{+}$ & $8.56 \pm 0.32$ \\
$\mathrm{~K}^{+}$ & $4.00 \pm 0.27$ \\
$\mathrm{Mg}^{++}$ & $11.8 \pm 0.20$ \\
$\mathrm{Ca}^{++}$ & $57.3 \pm 1.8$ \\
$\mathrm{SiO}_{2}(\mathrm{aq})$ & $10.4 \pm 0.96$ \\
$\mathrm{HCO}_{3}^{-}$ & $20.3 \pm 4.3$ \\
$\mathrm{SO}_{4}$ & $83.9 \pm 1.9$ \\
$\mathrm{Cl}^{-}$ & $76.6 \pm 1.3$ \\
$\mathrm{NO}_{3}^{-}$ & $10.7 \pm 0.29$ \\
$\mathrm{~F}^{-}$ & $2.16 \pm 0.09$ \\
\hline
\end{tabular}


Table 3. Water chemistry from experiment with SPW alone

\begin{tabular}{|c|c|c|c|c|c|}
\hline & $\begin{array}{l}\text { SPW } \\
\text { (evap3) }\end{array}$ & $\begin{array}{l}\text { Concentration } \\
\text { Factor: } 1243 x\end{array}$ & $\begin{array}{l}\text { Concentration } \\
\text { ratio }\end{array}$ & rewet & $\begin{array}{l}\text { Concentration } \\
\text { ratio }\end{array}$ \\
\hline \multicolumn{6}{|c|}{ ions $(\mathrm{mg} / \mathrm{kg})$} \\
\hline $\mathrm{pH}$ & 7.68 & $6-6.5 *$ & & 5.56 & \\
\hline $\mathrm{Na}^{+}$ & 8.2 & 5961 & 727 & 2077 & 253 \\
\hline $\mathrm{K}^{+}$ & 4.2 & 2779 & 661 & 973 & 232 \\
\hline $\mathrm{Mg}^{++}$ & 11.7 & 5478 & 470 & 1949 & 167 \\
\hline $\mathrm{Ca}^{++}$ & 57.2 & 15629 & 273 & 6010 & 105 \\
\hline $\mathrm{SiO}_{2}(\mathrm{aq})$ & 9.8 & 513 & 52 & 340 & 35 \\
\hline $\mathrm{HCO}_{3}^{-}$ & 16.2 & $<35$ & - & $<37$ & - \\
\hline $\mathrm{SO}_{4}^{--}$ & 81.7 & 2077 & 25 & 1564 & 19 \\
\hline $\mathrm{Cl}^{-}$ & 78.0 & 53084 & 681 & 19248 & 247 \\
\hline $\mathrm{NO}_{3}^{-}$ & 11.0 & $* *$ & $* *$ & 2647 & 241 \\
\hline $\mathrm{F}^{-}$ & 2.3 & $<577$ & - & $<301$ & - \\
\hline
\end{tabular}

* Estimate only using $\mathrm{pH}$ paper, which is semi-quantitative at best

** Sample accidentally spiked with $\mathrm{HNO}_{3}$ after $\mathrm{pH}$ measurement

Table 4. Water chemistry from experiment with SPW with tuff

\begin{tabular}{|c|c|c|c|c|c|}
\hline & SPW (evap6) & \multicolumn{2}{|c|}{ Concentration Concentration } & rewet & $\begin{array}{l}\text { Concentration } \\
\text { ratio }\end{array}$ \\
\hline ions $(\mathrm{mg} /$ & & & & & \\
\hline $\mathrm{pH}$ & 7.52 & 5.14 & & 5.43 & \\
\hline $\mathrm{Na}^{+}$ & 8.7 & 4420 & 508 & 3574 & 411 \\
\hline $\mathrm{K}^{+}$ & 4.1 & 2006 & 488 & 1622 & 395 \\
\hline $\mathrm{Mg}^{++}$ & 12.0 & 3615 & 300 & 2889 & 240 \\
\hline $\mathrm{Ca}^{++}$ & 59.2 & 12553 & 212 & 10249 & 173 \\
\hline $\mathrm{SiO}_{2}(\mathrm{aq})$ & 11.5 & 696 & 60.6 & 355 & 30.9 \\
\hline $\mathrm{HCO}_{3}^{-}$ & 20.2 & $<60$ & - & $<36$ & - \\
\hline $\mathrm{SO}_{4}^{--}$ & 85.2 & 1316 & 15.4 & 1516 & 17.8 \\
\hline $\mathrm{Cl}^{-}$ & 76.1 & 37198 & 489 & 30359 & 399 \\
\hline $\mathrm{NO}_{3}^{-}$ & 10.5 & 5267 & 501 & 4344 & 413 \\
\hline $\mathrm{F}^{-}$ & 2.1 & $<248$ & - & $<284$ & - \\
\hline
\end{tabular}


Table 5. $\mathrm{pH}$ and carbonate evolution from short-term experiment with SPW alone

\begin{tabular}{|c|c|c|}
\hline $\begin{array}{l}\text { Concentration } \\
\text { Factor } \\
\text { (evap5) }\end{array}$ & $\mathrm{pH}$ & $\left.\mathrm{HCO}^{-}{ }^{-} \mathrm{mg} / \mathrm{L}\right)$ \\
\hline 1.00 & 7.45 & 24.7 \\
\hline 1.06 & 8.69 & \\
\hline 1.38 & 9.01 & \\
\hline 1.76 & 8.99 & \\
\hline 2.31 & 8.86 & \\
\hline 4.19 & 8.57 & \\
\hline 6.09 & & 20.1 \\
\hline 6.36 & 8.55 & \\
\hline 8.16 & 8.51 & \\
\hline 8.19 & & 19.5 \\
\hline 12.0 & 8.45 & 19.4 \\
\hline 29.9 & 8.29 & 14.0 \\
\hline
\end{tabular}

Table 6. Water chemistry from short-term experiment with SPW water alone

\begin{tabular}{|l|c|c|c|}
\hline \multicolumn{1}{c}{} & \multicolumn{1}{c}{$\begin{array}{c}\text { SPW } \\
\text { (evap5) }\end{array}$} & $\begin{array}{c}\text { Concentration } \\
\text { Factor: 62x }\end{array}$ & $\begin{array}{c}\text { Concentration } \\
\text { Ratio }\end{array}$ \\
\hline ions (mg/kg) & & & \\
\hline $\mathrm{pH}$ & 7.45 & 7.65 & \\
\hline $\mathrm{Na}^{+}$ & 8.8 & 490 & 55.7 \\
\hline $\mathrm{K}^{+}$ & 3.7 & 248 & 67.1 \\
\hline $\mathrm{Mg}^{++}$ & 11.7 & 546 & 46.6 \\
\hline $\mathrm{Ca}^{++}$ & 55.6 & 1661 & 29.9 \\
\hline $\mathrm{SiO}_{2}(\mathrm{aq})$ & 9.8 & 476 & 48.4 \\
\hline $\mathrm{HCO}_{3}^{-}$ & 24.7 & 12.1 & 0.49 \\
\hline $\mathrm{SO}_{4}^{-}$ & 84.7 & 1557 & 18.4 \\
\hline $\mathrm{Cl}^{-}$ & 75.6 & 4202 & 55.6 \\
\hline $\mathrm{NO}_{3}^{-}$ & 10.5 & 580 & 55.3 \\
\hline $\mathrm{F}^{-}$ & 2.1 & 37.2 & 17.7 \\
\hline
\end{tabular}


Table 7. Mineralogical results from experiment with SPW alone

$\begin{array}{ll}\text { evap3 }-1243 \mathrm{x} & \text { evap3 - complete evaporation } \\ \text { gypsum }\left(\mathrm{CaSO}_{4}: 2 \mathrm{H}_{2} \mathrm{O}\right) & \text { gypsum }\left(\mathrm{CaSO}_{4}: 2 \mathrm{H}_{2} \mathrm{O}\right) \\ \text { tachyihydrite }\left(\mathrm{CaMg}_{2} \mathrm{Cl}_{6} \mathrm{O}_{10}: 12 \mathrm{H}_{2} \mathrm{O}\right)\end{array}$

Table 8. Mineralogical results from experiment with SPW with tuff

$\begin{array}{ll}\text { evap6-564x* } & \text { evap6- complete evaporation* } \\ \text { gypsum }\left(\mathrm{CaSO}_{4}: 2 \mathrm{H}_{2} \mathrm{O}\right) & \text { gypsum }\left(\mathrm{CaSO}_{4}: 2 \mathrm{H}_{2} \mathrm{O}\right) \\ \text { halite }(\mathrm{NaCl}) & \text { halite }(\mathrm{NaCl}) \\ & \text { Mg-smectite }\left(\mathrm{Na}_{3}(\mathrm{Al}, \mathrm{Mg})_{2} \mathrm{Si}_{4} \mathrm{O}_{10}(\mathrm{OH})_{2}\right) \\ & \text { Kenyaite? }\left(\mathrm{NaSi}_{11} \mathrm{O}_{20.5}(\mathrm{OH})_{4}: 3 \mathrm{H}_{2} \mathrm{O}\right)\end{array}$

* Only the minerals produced by evaporation and not present in the starting tuff are reported here. The tuff used is made up of: crystobalite (alpha), Kfeldspar, albite, anorthite, quartz (Bish et al., 1981).

Table 9. Mass of minerals formed in experiments with $\mathrm{SPW}^{*}$

\begin{tabular}{ll}
\hline SPW alone (evap3) & $11 \mathrm{~g}$ \\
SPW with tuff (evap6) & $15 \mathrm{~g}$
\end{tabular}

* Some of the minerals formed in these experiments were hygroscopic, making it impossible to obtain very accurate mass measurements. 